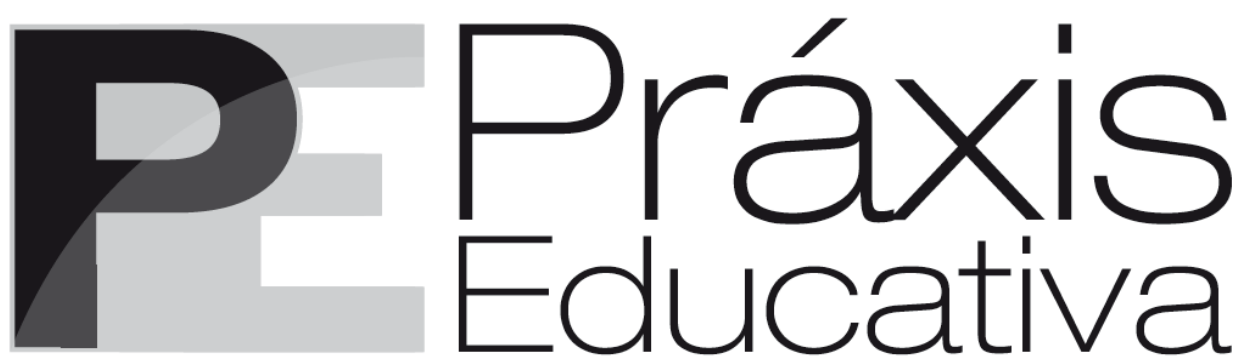

ISSN 1809-4031

elSSN 1809-4309

https://doi.org/10.5212/PraxEduc.v.16.16462.013

\title{
Resistir para existir: aportes freireanos para uma educação sexual transgressora e emancipadora
}

\section{Resist to exist: Freirean supports for transgressive and emancipatory sexual education}

\section{Resistir para existir: aportaciones freireanas para una educación sexual transgresora y emancipadora}

\author{
Fabiana Rodrigues de Sousa* \\ iD https://orcid.org/0000-0001-9963-0958
}

\begin{abstract}
Resumo: Este ensaio tem como objetivo desvelar as ressonâncias do pensamento de Paulo Freire e da feminista negra bell hooks para a proposição de uma educação sexual transgressora que promova a inserção crítica na realidade, o questionamento da heteronormatividade, a apropriação de uma linguagem de resistência, de modo a favorecer a construção da autonomia e a emancipação de sujeitos sexuais dissidentes. Reafirma-se, aqui, a relevância do legado freireano para consolidação de uma educação como prática da liberdade. $\mathrm{O}$ caráter emancipador do projeto educativo freireano catalisa o enfrentamento às estratégias reacionárias ocultas nos projetos de lei propostos pelo programa Escola Sem Partido, que visam minar a democracia, instaurar uma escola da mordaça e criminalizar educadoras e educadores que atuam na perspectiva da transformação social.
\end{abstract}

Palavras-chave: Paulo Freire. Educação sexual transgressora. Sexualidades dissidentes.

\begin{abstract}
This essay aims to reveal the resonances of Paulo Freire's thought and the black feminist bell hooks for the proposition of a transgressive sexual education that promotes critical insertion in reality, questioning heteronormativity, appropriation of a language of resistance, to favor the construction of autonomy and the emancipation of dissident sexual subjects. Here, the relevance of the Freirean legacy is reaffirmed for the consolidation of an education as a practice of freedom. The emancipatory character of the Freirean educational project catalyzes the confrontation of reactionary strategies hidden in the bills proposed by the Escola Sem Partido program, which aim to undermine democracy, establish a gag school and criminalize educators who work in the perspective of social transformation.
\end{abstract}

Keywords: Paulo Freire. Transgressive sexual education. Dissident sexualities.

\footnotetext{
* Professora do Programa de Pós-Graduação em Educação do Centro Universitário Salesiano de São Paulo (UNISAL). Doutora em Educação pela Universidade Federal de São Carlos (UFSCar). Parecerista ad hoc do GT06 Educação Popular da Associação Nacional de Pós-Graduação e Pesquisa em Educação (ANPEd). E-mail: $<$ fabiana.sante@unisal.br>.
} 
Resumen: Este ensayo tiene por objetivo revelar las resonancias del pensamiento de Paulo Freire y de la feminista negra bell hooks para la proposición de una educación sexual transgresora que promueva la inserción crítica en la realidad, el cuestionamiento de la heteronormatividad, la apropiación de un lenguaje de resistencia, de modo a favorecer la construcción de la autonomía y la emancipación de los sujetos sexuales disidentes. Se reafirma, aquí, la relevancia del legado freireano para la consolidación de una educación como práctica de libertad. El carácter emancipador del proyecto educativo de freireano cataliza el enfrentamiento de las estrategias reaccionarias ocultas en los proyectos de ley propuestos por el programa Escola Sem Partido, que buscan socavar la democracia, instaurar una escuela de la mordaza y criminalizar a los educadores y educadoras que actúan en la perspectiva de la transformación social.

Palabras clave: Paulo Freire. Educación sexual transgresora. Sexualidades disidentes.

\title{
Introdução
}

\author{
A escuridão estende-se mas não elimina \\ o sucedâneo da estrela nas mãos. \\ Certas partes de nós como brilham! São unhas, \\ anéis, pérolas, cigarros, lanternas, \\ são partes mais intimas, \\ a pulsação, o ofego, \\ $e o$ ar da noite é o estritamente necessário \\ para continuar, e continuamos. \\ Carlos Drummond de Andrade (1988, p. 26).
}

Uma das grandes lições que Paulo Freire nos ensinou, ao longo destes cem anos de história e esperança, não apenas com seus escritos, mas com seu exemplo de vida, foi a de que podemos lutar pelos mesmos ideais a vida inteira, inclusive nos tempos mais obscuros e difíceis (FLECHAGARCIA; PUIGVERT, 1998). Esse ensinamento é relevante, sobretudo, nesse período de incertezas que estamos atravessando, marcado pela banalização da vida, por ataques à democracia, à educação crítica e ao trabalho docente.

O trecho do poema "Nosso tempo", de Carlos Drummond de Andrade, apresentado nesta epígrafe, apesar de publicado originalmente em 1945, no livro A rosa do povo, ilustra bem as adversidades com que nos deparamos hoje para enfrentamento da onda neoconservadora que preconiza uma escola da mordaça, a fim de coibir a pronúncia coletiva e emancipadora do mundo e silenciar educadoras e educadores. Contudo, cientes de que onde há opressão há resistência, nos alicerçamos no legado freireano", esse "ar da noite", que nos faz "continuar, e continuamos" esperançando rumo a uma educação como prática da liberdade.

A política necrófila disseminada por essa onda neoconservadora, tanto no Brasil como no mundo, evidencia a propagação do fascismo social e suas diversas formas de dominação, nas sociedades contemporâneas. De acordo com Boaventura de Sousa Santos (2007, p. 80), o fascismo social é um regime "[...] de relações de poder extremamente desiguais, que concedem à parte mais forte poder de veto sobre a vida e o modo de vida da parte mais fraca".

Em meio à pandemia da Covid-19, os reflexos dessa política necrófila e neoliberal tornamse ainda mais claros nas ações de descaso no tocante à saúde, à assistência e à educação ofertadas à população brasileira, acirrando as desigualdades sociais. No Brasil, a marca desse fascismo é perceptível na crescente veiculação de discursos de ódio que enaltecem armas e apregoam a queima

\footnotetext{
${ }^{1}$ Embora as normas da Língua Portuguesa recomendem que o adjetivo antropônimo "freiriano" seja grafado com a letra "i", neste texto a palavra será grafada "freireano" com "e", a fim de obter proximidade da grafia do sobrenome "Freire".
} 
de livros, que orquestram a militarização das escolas públicas e a criminalização da pobreza por meio da defesa da redução da maioridade penal, na ampliação da violência policial contra as populações negras ${ }^{2}$ e não brancas que residem nas periferias e favelas, no aumento da violência contra a mulher e ocorrências de feminicídios, no elevado número de violência contra as populações LGBTQIA $^{+}$, muitas vezes resultando em mortes, principalmente de pessoas transexuais ${ }^{3}$. Discursos de ódio que negam o direito da coexistência nas diferenças e que se contrapõem às políticas públicas voltadas aos grupos populares, como as ações afirmativas e a política de cotas, banalizando-as como "vitimismo" ou "coitadismo".

É justamente nessa conjuntura necrófila e de advento do fascismo social que o educador Paulo Freire e sua obra têm sido alvos de inúmeros ataques materializados nas tentativas de revogação da Lei $\mathrm{N}^{\circ}$ 12.612, de 13 de abril de 2012, que o declara patrono da educação brasileira (BRASIL, 2012a) ou na articulação do controverso movimento Escola Sem Partido (ESP) e seus projetos de lei, cuja intenção é instaurar uma educação bancária e coibir toda forma de problematização, sobretudo de gênero e sexualidades nas escolas, por meio da perseguição a educadoras e educadores.

A respeito da controversa iniciativa do ESP, Lavoisier Santos, Valci Melo e Maria do Socorro Cavalcante $(2021$, p. 3) esclarecem que ela se caracteriza por duas vertentes, quais sejam: a primeira está relacionada à associação informal de pais, estudantes e dirigentes "[...] preocupados com o grau de contaminação político-ideológica das escolas"; e a segunda vertente abarca a formulação de projetos de lei nas esferas municipais, estaduais e federais. "[...] a referida iniciativa, em suas duas vertentes, tem entre seus alvos de ataque as ideias e a pessoa do educador Paulo Freire, responsabilizado, pela extrema direita principalmente no período eleitoral de 2018 - por todas as mazelas da educação brasileira” (SANTOS; MELO; CAVALCANTE, 2021, p. 3).

Todavia, o assalto contra a educação problematizadora e o pensamento freireano não é novidade na história brasileira, mas uma retomada do que ocorrera durante o período da ditadura militar (RAMOS; SANTORO, 2017). Não é, pois, coincidência, que os grupos e os setores conservadores que repudiam Paulo Freire e sua obra sejam os mesmos que saem às ruas clamando por intervenção militar.

O próprio Paulo Freire (2018), ciente da força de suas palavras contra as formas de opressão, já enunciava nas "Primeiras palavras" de sua "Pedagogia do Oprimido" que receberia críticas e causaria reações sectárias ${ }^{4}$ em alguns leitores que sequer conseguiriam ultrapassar as primeiras páginas de sua obra. Ante as ofensivas ao seu legado, faz-se necessário refletir por que os escritos do autor incomodaram, e seguem incomodando, indivíduos sectários, motivando-os a desenvolver estratagemas com vistas a "expurgar" Paulo Freire dos currículos escolares e formular projetos de leis com o intuito de criminalizar educadoras e educares que defendem uma educação dialógica e problematizadora.

Os sectários, como nos esclarece Freire (2018), prendem-se a seus círculos de segurança e, por isso, giram em torno de "sua" verdade, aquela que se coaduna a seus interesses. Acabam por

\footnotetext{
2 A respeito da violência policial contra a população negra e da periferia, consultar dados publicados no Relatório “A cor da violência policial: a bala não erra o alvo" (RAMOS, 2020).

${ }^{3}$ Em dados divulgados pela Associação Nacional de Travestis e Transexuais (ANTRA), o Brasil continua sendo o país que mais mata pessoas transexuais no mundo. Em 2019, ocorreram 124 assassinatos de pessoas trans. Destes, 21 ocorreram em São Paulo, tornando-o o estado brasileiro com maior ocorrência de mortes de pessoas transexuais (BENEVIDES; NOGUEIRA, 2020).

${ }^{4}$ São ações alienantes, míticas e irracionais que almejam falsear e obscurecer a realidade, dificultando a sua mudança e representando um obstáculo à emancipação dos seres humanos (FREIRE, 2018).
} 
sofrer da falta de dúvida, mitificam a realidade e sentem-se abalados na sua segurança, quando chamados à discussão ou problematização. Assim sendo, não podem conceber uma prática educativa que visa à conscientização de educandas e educandos.

A perseguição à obra freireana é orquestrada por sectários devido ao seu cunho revolucionário que remete ao conceito de conscientização e à compreensão das mulheres e dos homens como seres de práxis, ou seja, como sujeitos capazes de atuar, operar e transformar a realidade percebida de acordo com suas finalidades e intencionalidades. A capacidade humana de atuar e refletir sobre e no mundo, de conscientizar-se e engajar-se nos processos de transformação social é apontada, pelo autor, como condição para realização de um ato comprometido. Mulheres e homens, ao experienciarem esse compromisso de modo "corajoso, decidido e consciente", não podem mais se perceber ou dizer neutros (FREIRE, 2010, p. 19). "A neutralidade frente ao mundo, frente ao histórico, frente aos valores, reflete apenas o medo que se tem de revelar o compromisso. Este medo quase sempre resulta de um 'compromisso' contra os homens, contra sua humanização, por parte dos que se dizem neutros” (FREIRE, 2010, p. 19).

Por esse motivo, ao longo de seus escritos, Paulo Freire sempre negou a existência de uma prática educativa neutra, descomprometida e apolítica: "A diretividade da prática educativa que a faz transbordar sempre de si mesma e perseguir um certo fim, um sonho, uma utopia, não permite sua neutralidade" (FREIRE, 2003, p. 37). Essa diretividade não tem nada a ver com a imposição arbitrária de opções, convicções e sonhos por parte de educadoras e educadores às educandas e aos educandos, o que caracterizaria a "doutrinação". A diretividade inerente à prática educativa alude ao posicionamento político de educadoras e educadores diante das inúmeras injustiças sociais (de classe, de gênero, de orientação sexual, étnico-raciais, geracional, etc.), levando ao engajamento no compromisso autêntico e solidário de lutar com educandas e educandos em direção à humanização e à superação das opressões e das injustiças identificadas.

A educação pode, então, concretizar-se como práxis de libertação, ao possibilitar os questionamentos: a favor de que/de quem educamos? Contra que/quem educamos? (FREIRE, 1998, 2008, 2018). As respostas a tais questionamentos explicitam que a educação é sempre política e não neutra, uma vez que exige a assunção de um posicionamento político seja a favor da superação das opressões e das injustiças sociais ou da manutenção do status quo. Pois, como nos ensina Freire (2010), o verdadeiro compromisso de educadoras e educadores populares é a solidariedade com as pessoas que são desumanizadas, coisificadas e proibidas de ser. Essa solidariedade com as pessoas oprimidas, que historicamente vêm sendo proibidas de ser, figura como um princípio de seu legado que se contrapõe à "ética do mercado" e às políticas neoliberais que pretendem converter a educação em mais uma mercadoria.

Na sua "Pedagogia da autonomia", Freire (1998, p. 145) sabiamente anunciava que essa solidariedade aguçaria uma espécie de mal-estar frente à "maldade neoliberal". Isso terminaria por “[...] consolidar-se numa rebeldia nova em que a palavra crítica, o discurso humanista, o compromisso solidário, a denúncia veemente da negação do homem e da mulher e o anúncio de um mundo 'genteficado" (FREIRE, 1998, p. 145) se converteriam em armas de alcance incalculável na luta contra a "ética do mercado" e em favor da ética universal do ser humano.

Em uma época de apagamento da memória, em que a relevância política da educação é negada em decorrência da imposição da medição e da quantificação, torna-se, ainda mais, relevante lembrarmo-nos dos ensinamentos de Paulo Freire (GIROUX, 2016). Assim, este ensaio analítico tem como objetivo reafirmar a validade e a atualidade da obra de Paulo Freire, no campo da Educação e das Ciências Humanas, com intenção de desvelar ressonâncias de sua obra no campo dos estudos de gênero e de sexualidades. Para tanto, são analisadas as estratégias discursivas dos projetos de lei formulados pelo controverso movimento ESP que associam Paulo Freire, bem 
como educadoras e educadores freireanos, a processos de "doutrinação política de esquerda", com intuito de elucidar que tais artimanhas linguísticas ocultam a real intenção de tentar frear os avanços democráticos obtidos no país. Por fim, são tecidas considerações sobre aportes freireanos e sua contribuição para a proposição de uma educação sexual transgressora comprometida com a problematização de gêneros, sexualidades e com uma política educativa biófila ancorada na humanização e na busca por Ser Mais como vocação ontológica (FREIRE, 2018).

\title{
Barrar a transição da sociedade: entrelinhas reacionárias das ofensivas a Paulo Freire
}

\author{
Este é tempo de partido, \\ Tempo de homens partidos. \\ Calo-me, espero, decifro. \\ As coisas talvez melhorem. \\ São tão fortes as coisas! \\ Mas eu não sou as coisas e me revolto. \\ Tenho palavras em mim buscando canal, \\ são roucas e duras, \\ irritadas, enérgicas, \\ comprimidas há tanto tempo, \\ perderam sentido, apenas querem explodir. \\ Carlos Drummond de Andrade (1988, p. 25).
}

Esse outro trecho do poema supracitado de Drummond também apresenta similaridades com a atual conjuntura política, já que novamente vivenciamos um tempo de polaridades característico de uma sociedade em transição. Neste período, em que se acirra a perseguição ao trabalho docente e tentativas de silenciar educadoras e educadores, nossas palavras "apenas querem explodir" expressando a necessidade de transgredir e resistir às investidas neoliberais que difundem a neutralidade política como forma de perpetuar a alienação social.

Ernani Fiori (2018) sabiamente destacava que uma educação como prática da liberdade é aquela que possibilita a pronúncia coletiva do mundo àqueles que são silenciados e se encontram proibidos de ser. Pronunciar o mundo coletivamente consiste em transformá-lo, não aceitar o fatalismo - sendo esse o grande motivo da perseguição ao pensamento e à obra de Paulo Freire, bem como a educadoras e educadores que, com ele, comungam.

É por isso que a defesa de uma pedagogia da pergunta pautada na problematização da realidade só pode ser feita por quem partilha de compromisso autêntico de construir um mundo comum (democrático, anticolonial, antirracista, antipatriarcal, anti-heteronormativo etc.), identificando-se, portanto, com uma educação libertadora e dialógica, como proposta por Paulo Freire. Do mesmo modo, aqueles que refutam o legado freireano e coadunam-se ao sectarismo, passam a defender uma escola da mordaça e uma educação bancária que promove a passividade, o silêncio, a ausência de criticidade e a adaptação dos indivíduos.

Moacyr Ramos e Ana Cecília Santoro (2017) traçaram um paralelo entre a perseguição sofrida por docentes, atualmente, e a sofrida por Paulo Freire, durante o período da ditadura militar, e concluem que os movimentos de controle e criminalização da docência revelam a fragilidade do processo de redemocratização de nosso país marcado por um "gradualismo" próprio a um modo de transição fraco. Esse modo de transição fraco pode ser compreendido por meio do conceito de introjeção da sombra do opressor, de que nos fala Freire (2018), comumente perceptível em países 
marcados por colonialismos e colonialidade ${ }^{5}$. No livro Educação e mudança, publicado no Brasil em 1979, Freire (2010) comenta acerca do processo de transição social:

[...] uma sociedade está se abrindo quando começa o processo de desalienação com o surgimento de novos valores. Assim, por exemplo, a ideia da participação popular no poder. Nesta sociedade em transição se está numa posição progressista ou reacionária; não se pode estar com os braços cruzados. É preciso procurar uma nova escala de valores. O velho e o novo têm valor na medida em que são válidos, ou se dirige a sociedade para ontem ou para o amanhã que se anuncia hoje. As atitudes reacionárias são as que não satisfazem o processo e os valores requeridos pela sociedade de hoje. (FREIRE, 2010, p. 36-37).

A sociedade brasileira, nesse processo de desalienação, vem gestando novos valores à medida que denúncia, com vistas a superá-las, as marcas da colonialidade que ainda se fazem presentes nas relações sociais, seja no patriarcalismo que perpetra hierarquizações e relações de poder dos homens sobre as mulheres, no racismo estrutural que é fruto do eurocentrismo que privilegia brancos, em detrimento aos demais grupos étnico-raciais (populações negras e afrodescendentes, indígenas, ciganas, etc.), na lógica heteronormativa que perpetua relações binárias e nega formas plurais de identidade de gênero e de vivência das sexualidades, na estrutura de exploração e dominação da natureza, dentre outras.

Nesse sentido, Paulo Freire destaca a importância de uma educação crítica e problematizadora para a promoção de avanços sociais, econômicos e políticos no país. Todavia, para romper com a colonialidade, as sociedades alienadas, além de gestarem novos valores democráticos, precisam passar a se ver com seus próprios olhos, expulsando, assim, a sombra do opressor. Quando isso ocorre, a desesperança vai sendo substituída por um clima de esperança e essas sociedades vão tornando-se capazes de projetar novos sonhos possíveis.

\begin{abstract}
Sonhar não é apenas um ato político necessário, mas também uma conotação da forma histórico-social de estar sendo de mulheres e homens. Faz parte da natureza humana que, dentro da história, se acha em permanente processo de tornar-se. Fazendo-se e refazendo-se no processo de fazer a história, como sujeitos e objetos, mulheres e homens, virando seres da inserção no mundo e não da pura adaptação ao mundo terminaram por ter no sonho também um motor da história. Não há mudança sem sonho como não há sonho sem esperança. (FREIRE, 2008, p. 91).
\end{abstract}

O sonho de uma sociedade mais equânime alimentou nossas esperanças, mobilizando-nos na luta social que resultou em avanços em direção a aspirações democráticas, de tal forma que os grupos populares passaram não apenas a reivindicar acesso a direitos humanos, mas também a exigir qualidade e equidade (MASAGÃO, 2016). Como exemplo desses avanços, tem-se a consolidação da Lei de Diretrizes e Bases - Lei No 9.394, de 20 de dezembro de 1996, que apregoa a gestão democrática como princípio da educação nacional (BRASIL, 1996); a Lei No 10.639, de 9 de janeiro de 2003, que dispõe sobre o ensino de cultura e história das populações afro-brasileira e africana (BRASIL, 2003); a Lei $\mathrm{N}^{\circ}$ 11.645, de 10 de março de 2008, que versa sobre a obrigatoriedade do ensino de cultura e história afro-brasileira e indígena na rede oficial de ensino (BRASIL, 2008); a Lei No 12.711, de 29 de agosto de 2012, que dispõe sobre a adoção de cotas (raciais e sociais) para ingresso em instituições federais de Ensino Superior, de ensino técnico e médio (BRASIL, 2012b). Entretanto, como já asseverava Freire (2010), a toda ação progressista e esperançosa no sentido da transformação das estruturas sociais opressivas corresponde uma reação

\footnotetext{
${ }^{5}$ Conceito cunhado por Aníbal Quijano e desenvolvido por autoras e autores como Catherine Walsh, Edgardo Lander, Ramón Grosfogel, Walter Mignolo, dentre outros ligados ao grupo Colonialidade/Modernidade. Para Quijano (2005), o colonialismo requer uma racionalidade que a sustente - a colonialidade. Esta engloba uma série de ações e valores que definem o imaginário social eurocêntrico, projetando a Europa como centro do sistema-mundo e naturalizando a hierarquização entre seres humanos por meio de critérios, por exemplo, como "raça" e "gênero", dentre outros.
}

Práxis Educativa, Ponta Grossa, v. 16, e2116462, p. 1-18, 2021 Disponível em: <https://www.revistas2.uepg.br/index.php/praxiseducativa> 
com objetivo de manutenção do status quo. Em consonância a esse entendimento, Masagão (2016) analisa que as arremetidas de grupos conservadores, como o ESP, são

[...] reações frente aos avanços que a sociedade brasileira vem realizando na direção de aspirações democráticas e igualitárias expressas na Constituição de 1988. Além da importante redução da pobreza e maior acesso ao consumo, a ampliação dos serviços públicos de educação e saúde vem lentamente desenhando um novo país, com uma população que reconhece cada vez mais que tem direitos. Dificilmente o país voltará a ser um terreiro de coronéis, onde se aceite com naturalidade a violência contra a mulher, o racismo e a homofobia, a exclusão e as desigualdades. (MASAGÃO, 2016, p. 7).

Destarte, os atentados ao pensamento freireano e as estratégias de associá-lo a processos de "doutrinação política" são atitudes reacionárias que intencionam perpetuar práticas de educação bancária, a fim de barrar o processo de democratização da sociedade para garantir a manutenção de privilégios aos grupos dominantes. Apesar da falácia da defesa da família, da moral e dos bons costumes, esses grupos reacionários almejam dificultar a consolidação de práticas educativas críticas comprometidas com a construção de valores sociais emancipadores e descolonizadores.

O discurso desse grupo que pretende deslegitimar o pensamento freireano, ademais, não esconde a ideologia machista e sexista de onde parte, subsumindo a presença das mais de $80 \%$ de mulheres da educação básica, tratando-as como "professores". Suas ideias, concepções, esperanças, dúvidas, valores, desafios, desaparecem na declinação do masculino como genérico. $\mathrm{E}$ isso se traduz como colonialidade e patriarcado, o que professam inconfessadamente. Sob a égide da "normalidade", do "natural", da "ordem" e do "progresso", a escola com mordaça segue tentando fazer as professoras desaparecerem sob as costelas dos homens [...]. (VASCONCELOS; BRANDÃO, 2018, p. 306).

Como nos ensina Freire, o processo de transição da sociedade não pode concretizar-se sem que haja conflitos e disputas políticas em torno da consolidação da "nova ordem", seja ela fruto de diálogo e da participação social ou de uma construção autoritária e imposta de cima para baixo. Assim sendo, quem nega a transitividade da sociedade acaba por rotular aquelas e aqueles que se integram no dinamismo do trânsito social de "subversivos", pois "ameaçam a ordem" instaurada e as estruturas - sexistas, machistas, racistas, heteronormativas, neoliberais, exploratórias - que a sustentam. "Esquecem-se, porém, de que o conceito de ordem não é só do mundo estético, físico ou ético, mas também histórico-sociológico" (FREIRE, 2014, p. 76) e, consequentemente, pode ser recriado, a partir de novos valores sociais como solidariedade, justiça, amorosidade, coletividade, dialogicidade, equidade, igualdade de diferenças, partilha, etc.

A criação de estratagemas para mascarar a realidade e escamotear o intuito desses grupos sectários de proteger a si e a seus próprios interesses é um mecanismo de dominação que vem sendo reatualizado nas investidas contra o trabalho docente e o pensamento de Paulo Freire. Subterfúgios linguísticos que foram utilizados outrora, no período da ditadura militar, são observados novamente na veiculação de rótulos que recaem à educação e aos docentes como "doutrinadores políticos", "subversivos", "comunistas" ou "educação pintada de vermelho" (RAMOS; SANTORO, 2017). Tais rótulos evidenciam que, apesar da propalada defesa da "ordem" e da "neutralidade" da educação, se oculta o desejo de instaurar um clima de perseguição e silenciamento a educadoras e educadores, como forma de dificultar a efetivação de práticas educativas conscientizadoras no âmbito escolar e frear o processo de construção de novos valores sociais.

Convém atentar que, mesmo sem a aprovação do Programa Escola Sem Partido, a atuação do Movimento Escola Sem Partido já tem sido suficiente para criar uma onda de perseguição docente no interior das instituições escolares. Por isso, têm sido cada vez mais comuns casos de professores afastados de suas funções por "atividade subversiva" e "doutrinação ideológica". Com base nas orientações dadas pelo movimento, alunos

Práxis Educativa, Ponta Grossa, v. 16, e2116462, p. 1-18, 2021

Disponível em: < https://www.revistas2.uepg.br/index.php/praxiseducativa> 
estão denunciando seus professores, num clima de desconfiança, descrédito e de elaboração de armadilhas, com gravação de vídeos e áudios escondidos, os quais, na maior parte dos casos, captam fragmentos de aulas, sem qualquer contextualização, buscando criminalizar qualquer trabalho de conscientização. (RAMOS; SANTORO, 2017, p. 144).

A utilização de recursos discursivos por integrantes e apoiadores do ESP para causar medo e criar um clima de ódio aos educadores e às educadoras é objeto de análise de Fernando Penna (2016). O autor analisa que o primeiro recurso empregado consiste na adoção de termos genéricos, como "doutrinação ideológica", "ideologia de gênero" e "marxismo cultural", cuja ausência de uma definição precisa abre margem para que diversos casos sejam enquadrados e deturpados por meio do uso dessas terminologias. O segundo recurso é a desqualificação de educadoras e educadores, da própria escola e de referenciais utilizados no trabalho docente. Contudo, a desqualificação não se efetiva por meio de argumentação racional, mas, sim, por ataques pessoais e/ou uso de imagens em que as educandas/educandos figuram como inocentes e educadoras/educadores como ameaça. Dentre essas imagens, destaca-se uma que aponta a/o educadora/educador e a escola/universidade, respectivamente, como agente e espaço de corrupção de menores. "O primeiro e o segundo procedimentos se articulam: o uso de termos que não têm uma definição precisa para indicar uma ameaça abstrata que coloca em suspeição todos os professores e todo o sistema escolar" (PENNA, 2016, p. 95).

Essa artimanha da linguagem também é perceptível na redação de diversos projetos de lei ligados ao ESP, e estava presente na redação do Projeto de Lei No 193/2016 (BRASIL, 2016), de autoria do senador e pastor evangélico Magno Malta (PR-ES), que prescrevia a inclusão do Programa Escola Sem Partido na Lei de Diretrizes e Bases da Educação Nacional (Lei N $^{\circ}$ 9.394/1996). Após sofrer fortes críticas e receber relatório de rejeição da proposta, o próprio autor solicitou a retirada do projeto de lei e o mesmo fora arquivado.

Em seu artigo segundo, o Projeto de Lei dispunha que a educação nacional tivesse como um dos seus princípios a: "neutralidade política, ideológica e religiosa do Estado" (BRASIL, 2016, p. 1), e adiante, em parágrafo único do mesmo artigo, prescrevia que:

O Poder Público não se imiscuirá na orientação sexual dos alunos nem permitirá qualquer prática capaz de comprometer o desenvolvimento de sua personalidade em harmonia com a respectiva identidade biológica de sexo, sendo vedada, especialmente, a aplicação dos postulados da teoria ou ideologia de gênero. (BRASIL, 2016, p. 1-2).

Uma leitura atenta do projeto leva-nos a questionar sua coerência, já que, por um lado, defendia a neutralidade política, ideológica e religiosa do Estado como um dos princípios da educação nacional; e, por outro, afirmava que o Poder Público não adotaria tal neutralidade no tocante à orientação sexual de educandas e educandos, pois coibiria práticas consideradas capazes de comprometer o desenvolvimento da personalidade em "[...] harmonia com a respectiva identidade biológica de sexo [...]" (BRASIL, 2016, p. 1-2). Percebe-se, aqui, uma manobra de grande teor político, embora não explicitada, que visa a reduzir a escola a mero aparelho ideológico do Estado, cuja função social seria disseminar a ideologia da classe dominante garantindo a manutenção da ordem social vigente (ALTHUSSER, 1986). A escola, nessa concepção, teria como função (hetero)normatizar os corpos, moldando as personalidades de educandas e educandos em "harmonia" com o sexo biológico, ignorando, dessa forma, a dimensão social e cultural das sexualidades e das identidades de gênero.

Assim, as entrelinhas do projeto de lei dão indícios de que ele preconizava, mas estava longe de acatar, a pretensa neutralidade política anunciada como um dos princípios da educação nacional. 
E que de neutro não tinha nada, já que objetivava perpetuar os preceitos da heteronormatividade, revelando, dessa forma, uma prática comum à bancada evangélica fundamentalista que costuma ignorar a laicidade, este sim um princípio da educação nacional, e se pautar em preceitos de sua religião para formular, analisar e aprovar - ou reprovar - projetos de lei e políticas públicas. Conforme pode ser observado na postura adotada por esta bancada diante de leis que abordam a descriminalização do aborto, o reconhecimento da união entre pessoas do mesmo sexo, a regulamentação da prostituição, o acesso aos direitos sexuais e reprodutivos, etc.

Desvelar o que se oculta nas entrelinhas dos discursos proferidos por integrantes do ESP, em seus projetos de lei ou nas mensagens veiculadas nas redes sociais, evidencia que aqueles que não assumem o compromisso autêntico com a transformação social não o fazem porque " [...] estão 'comprometidos' consigo mesmos, com seus interesses ou com os interesses dos grupos aos quais pertencem. E como este não é um compromisso verdadeiro, assumem a neutralidade impossível" (FREIRE, 2010, p. 19).

O PL No 193/2016, em vez de perceber as escolas e a educação que ali se desenvolvem, como campos profícuos para o diálogo e problematização da realidade, almejava confundir a população e enfraquecer a leitura crítica do mundo, pois se ancorava em uma abordagem reducionista, na qual educadoras e educadores devem agir como meros transmissores de conteúdos, negligenciando, assim, as dimensões críticas e políticas da educação.

Ao analisar a atuação do ESP, Frei Betto denuncia que essa tendência de procurar acobertar a realidade com palavras é uma velha artimanha daqueles que são favoráveis à manutenção do status quo. Frei Betto (2016, p. 67) adverte-nos de que muitos dos que se declaram "sem partido" são, na verdade, "[...] partidários de ensinar que nascemos todos de Adão e Eva; homossexualidade é doença e pecado (e tem cura!); identidade de gênero é teoria promíscua; e o capitalismo é o melhor dos mundos". Ora, se este é o melhor dos mundos, não convém problematizar a realidade para que juntos percebamos que a "[...] desigualdade social decorre da opressão sistêmica; a riqueza, do empobrecimento alheio; a homofobia, do machismo exacerbado; a leitura fundamentalista da Bíblia da miopia que lê o texto fora do contexto" (BETTO, 2016, p. 67).

No entanto, como aprender a ler o texto dentro do contexto sem problematizar a realidade? Sem buscar investigar as razões de ser das coisas? De acordo com Freire (1998), para conhecer as razões de ser do objeto cognoscível é preciso assumir uma atitude séria e curiosa diante dele, procurando estudá-lo com intenção de compreender o que o faz ser como está sendo.

Essa artimanha de tentar acobertar a realidade com palavras e censurar outras palavras evidencia-se no atual cenário brasileiro não apenas na redação de projetos de lei que tentam forjar uma escola com mordaça, mas também se dá a ver no posicionamento adotado pela diplomacia brasileira do atual Governo Federal que se aliou a países ultraconservadores para impedir a inclusão do termo "educação sexual" em uma resolução da Organização das Nações Unidas (ONU), além de vetar a expressão "saúde sexual e reprodutiva", em redação proposta por países africanos com o intuito de banir a mutilação genital feminina. Representantes do Governo Federal alegam que tais termos podem dar margem a iniciativas do que denominam como "ideologia de gênero" ou incentivar práticas de aborto (CHADE, 2020).

\footnotetext{
${ }^{6} \mathrm{O}$ vocábulo alude à normatização social de desejos, sexualidades, condutas e identificações de gêneros tidos como normais e "naturais" quando ajustados ao par binário masculino/feminino. Assim todas as variações da norma heterossexual binária - tais como a homossexualidade, lesbianidade, transexualidade, transgeneridade, intersexualidade, travestilidade, etc. - são consideradas desviantes, marginalizadas e são reprimidas por colocar em risco a ordem sexual vigente.
} 
Frente a esse panorama político brasileiro, marcado por graves ameaças à democracia e por incertezas no tocante à garantia de direitos conquistados pela luta de diversos movimentos sociais, não podemos deixar de lutar em defesa de uma educação crítica, política, problematizadora e dialógica, pois o engajamento na transformação da realidade e a percepção dos limites e dos alcances da prática político-educativa dependem da compreensão dos conflitos sociais (de classes, étnico-raciais, geracionais, de gênero, de orientação sexual, religiosos, etc.) bem como de nosso nível de organização.

É mister pontuar que essa organização está acontecendo e que respostas aos ataques sofridos já vêm se convertendo em alguns avanços no tocante à jurisprudência quanto à inconstitucionalidade de projetos de lei que procuram impor uma escola da mordaça. Como exemplo dessa jurisprudência, tem-se a decisão do Plenário do Supremo Tribunal Federal (STF) que, em abril de 2020, declarou por unanimidade a inconstitucionalidade da Lei $\mathrm{N}^{\circ} 1.516 / 2015$, de autoria dos vereadores Danilo Ferreira e Alan Simplício do município de Novo Gama, no estado de Goiânia, que almejava vetar a discussão de gênero nas escolas e que proibia "material com informações de ideologia de gênero" (BRASIL, 2020, n.p.). No entendimento da Procuradoria Geral da República (PGR), a lei do município goiano é inconstitucional por ferir a laicidade do Estado, o direito à igualdade, bem como o direito à liberdade de aprender, ensinar, pesquisar e divulgar o pensamento.

Por sua vez, em 2017, o STF já havia suspendido outras duas leis relacionadas ao ESP. A primeira delas, a Lei N $\mathrm{N}^{\circ}$ 7.800/2016, do estado de Alagoas, que foi suspensa em março de 2017 e instituía o programa "Escola Livre", que visava "livrar" a escola, no sistema educacional estadual, da chamada "doutrinação política e ideológica" e proibir que professores incitassem estudantes a participar de manifestações, atos públicos ou passeatas (BRASIL, 2017a). Com base em informações veiculadas na página do STF, foi concedida liminar na Ação Direta de Inconstitucionalidade (ADI) para suspender a integralidade da lei, por considerar que ela violava a competência da União para legislar sobre as diretrizes e bases da educação nacional prevista na Constituição Federal em seu artigo 22. Outro motivo apontado para justificativa da liminar foi o uso de termos vagos como "educação moral livre de doutrinação política, religiosa e ideológica" e proibição de "propaganda religiosa, ideológica ou político-partidária" (BRASIL, 2017a, n.p.) por parte do professor, sem a apresentação de critérios mínimos para definição de tais conceitos, corroborando a denúncia feita por Penna (2016) em sua análise acerca dos projetos de lei propostos pelo ESP.

A segunda liminar foi dada, em junho, à Lei $\mathrm{N}^{\circ} 3.468 / 2015$, que aprovava o Plano Municipal de Educação de Paranaguá, no estado do Paraná, e vedava o ensino sobre gênero e orientação sexual nas escolas do município. A suspensão à norma do referido município justificase, com base nas informações disponíveis no site do STF (BRASIL, 2017b), por considerar que o veto aos conteúdos ligados a temáticas do campo de gênero e sexualidade relegava os educandos e as educandas à ignorância em relação a uma dimensão fundamental da experiência humana. Argumenta-se, ainda, que a homossexualidade e a transexualidade não deixarão de existir em decorrência de sua negação nos currículos escolares.

Essas conquistas fortalecem a organização e a luta pela construção de uma educação democrática, crítica e libertadora, conforme os preceitos freireanos. Pois, cientes da posição como sujeitos de nossa história, educadoras e educadores críticos, sabemos que o mundo que sonhamos é fruto de práxis e, portanto, de nossa atuação e de nosso engajamento na transformação da realidade. 


\title{
Tecendo uma educação sexual transgressora e emancipadora
}

As ressonâncias dos aportes freireanos têm contribuído para a proposição de uma educação sexual transgressora voltada à emancipação de sujeitos que vivenciam sexualidades dissidentes ${ }^{7}$ como lésbicas, gays, travestis, transexuais, bissexuais, pansexuais e prostitutas. Ao longo de sua vasta obra, Paulo Freire abordou diversas temáticas e, conquanto não tenha se voltado especificamente à discussão de gênero e sexualidade, estudiosas e estudiosos de seu legado vêm pautando-se em seus escritos a fim de tecer uma educação sexual transgressora e emancipadora.

A concepção de uma educação transgressora tem como principal aporte teórico o trabalho de bell hooks ${ }^{8}$ que, por sua vez, se inspira na concepção de educação crítica e libertadora de Paulo Freire. Em seu livro Ensinando a transgredir: a educação como prática da liberdade, a feminista negra bell hooks (2017) discorre sobre as influências dos escritos freireanos em sua obra, as quais se dão a ver em sua busca por aliar teoria e prática e na sua percepção da teoria como lugar de cura e de libertação coletiva.

\begin{abstract}
Quando nossa experiência vivida da teorização está fundamentalmente ligada a processos de autorrecuperação, de libertação coletiva, não existe brecha entre a teoria e a prática. Com efeito, o que essa experiência mais evidencia é o elo entre as duas - um processo que, em última análise, é recíproco, onde uma capacita a outra. A teoria não é intrinsecamente curativa, libertadora e revolucionária. Só cumpre essa função quando lhe pedimos que o faça e dirigimos nossa teorização para esse fim. (HOOKS, 2017, p. 8586).
\end{abstract}

A teorização passa a exercer a função de libertação quando se dirige à problematização da realidade, proporcionando que sujeitos que vivenciam opressões possam refletir sobre sua dor com vistas a superá-la. Destarte, um dos princípios da educação sexual transgressora é favorecer esse uso contra-hegemônico da teoria que, quando empregada como intervenção para desafiar o status quo, como nos ensina hooks (2017) e Freire (2018), possibilita novas formas de olhar o mundo e de atuar sobre ele. Ao refletir sobre o racismo e a segregação racial que vivenciou, hooks (2017) revela que encontrou um refúgio na "teorização" que the possibilitou entender o que estava acontecendo ao seu redor.

Encontrei um lugar onde eu podia imaginar futuros possíveis, um lugar onde a vida podia ser diferente. Essa experiência "vivida" de pensamento crítico, de reflexão e análise se tornou um lugar onde eu trabalhava para explicar a mágoa e fazê-la ir embora. Fundamentalmente, essa experiência me ensinou que a teoria pode ser um lugar de cura. (HOOKS, 2017, p. 85).

Para os sujeitos sexuais dissidentes, a teoria como cura pode colaborar na percepção de que a sexualidade tem uma história e que é resultado de uma construção social e cultural. Isso motiva lésbicas, gays, travestis, transexuais, bissexuais, pansexuais e prostitutas a questionarem a naturalização das relações reprodutivas e sexuais, bem como os discursos regulatórios que oprimem

\footnotetext{
${ }^{7}$ O termo "sexualidades dissidentes", cunhado por Gayle Rubin (2012), alude às sexualidades marginalizadas que são alvo de reprovação moral. Aquelas/aqueles que exercem alguma forma de atividade sexual marginalizada, seja por cobrar por sexo (prostitutas e demais trabalhadoras/es do sexo), por sentir atração sexual por pessoas do mesmo sexo (gays, lésbicas), por ambos os sexos (bissexuais) ou independentemente do sexo (pansexuais), por romper com as normas binárias (transexuais, travestis, intersexuais), dentre outras, passam a compor uma população sexual dissidente da heteronormatividade.

${ }^{8}$ bell hooks é o pseudônimo adotado pela teórica e ativista feminista Gloria Jean Watkins, em seus livros. A grafia é realizada em letras minúsculas para marcar o desejo da autora de salientar que a substância de suas obras importa mais do que quem ela é. Em consonância com seu posicionamento político, neste artigo, será mantida a grafia em letras minúsculas.
}

Práxis Educativa, Ponta Grossa, v. 16, e2116462, p. 1-18, 2021 Disponível em: <https://www.revistas2.uepg.br/index.php/praxiseducativa> 
e invisibilizam seus corpos dissidentes por transgredirem o que é estipulado como normal, moral, natural, saudável, seguro e aceitável no tocante às atividades sexuais.

Aprender a utilizar a teoria como cura é o que permite a emersão das consciências, de que nos fala Freire (2018), facilitando a inserção crítica na realidade. Quanto mais mulheres e homens problematizem a si e ao mundo, mais se reconhecerão como seres no e com o mundo. Assim, tanto mais se sentirão desafiados e responderão a esses desafios. Todavia, "[...] precisamente porque captam o desafio como um problema em suas conexões com outros, num plano de totalidade e não como algo petrificado, a compreensão resultante tende a tornar-se crescentemente crítica, por isto, cada vez mais desalienada" (FREIRE, 2018, p. 98).

A inserção crítica é, pois, outro elemento da educação sexual transgressora, uma vez que favorece a problematização da dimensão política da sexualidade e das disputas, conflitos e tensões que forjam hierarquias a fim de conformar uma "normalidade" e estigmatizar corpos dissidentes. Como destaca Gayle Rubin (2012), em tempos de crise e estresse social, potencializam-se as disputas e a vigilância acerca do comportamento sexual que se torna veículo para o deslocamento das ansiedades sociais, assim como temos observado nas investidas dos grupos conservadores e adeptos do ESP.

A esfera da sexualidade também tem sua política interna, desigualdades, e modos de opressão. Como em outros aspectos do comportamento humano, as formas institucionais concretas da sexualidade em um determinado tempo e lugar são produto da atividade humana. São imbuídas de conflitos de interesse e manobras políticas, ambas deliberadas e incidentais. Nesse sentido, o sexo é sempre político. Mas há períodos históricos em que a sexualidade é mais nitidamente contestada e mais excessivamente politizada. (RUBIN, 2012, p. 1).

Por conseguinte, as opressões que permeiam as sexualidades podem e devem ser superadas pela ação humana. O objetivo de uma educação sexual transgressora é desnaturalizar as formas institucionais e normatizadas de vivenciar as sexualidades, desvelando-as como construções sociais. É preciso, pois, problematizar que as sexualidades não consistem em “algo 'dado' pela natureza, inerente ao ser humano" e que nem "todos vivemos nossos corpos, universalmente, da mesma forma" (LOURO, 2007, p. 11). Ratificando esse entendimento, Richard Parker (2007) complementa:

\begin{abstract}
Isso coloca uma atenção renovada no fato de que a desigualdade de gênero e a opressão sexual não são fatos imutáveis da natureza, mas sim artefatos da história, ajudando a nos fazer lembrar que as estruturas da desigualdade e da injustiça, que tão frequentemente parecem organizar o campo sexual, bem como outras formas de injustiça social, podem, de fato, ser transformadas através da ação intencional e de iniciativas políticas progressistas. (PARKER, 2007, p. 144).
\end{abstract}

Uma iniciativa política progressista consiste, pois, em considerar a escola como um dos espaços profícuos para a concretização de uma educação sexual transgressora capaz de fomentar a problematização da sexualidade e a inserção crítica na realidade. Segundo Paulo Freire (2018, p. 98), a inserção crítica na realidade vai gerando "novas compreensões de novos desafios", à medida que os sujeitos vão criando respostas ao que lhes desafiam e, assim, vão expulsando a sombra do opressor e assumindo o compromisso autêntico com a transformação da realidade percebida.

Ao analisarem as conexões entre o pensamento de Paulo Freire e as lutas implementadas pelo Movimento LGBTQIA ${ }^{+9}$, Cleyton Pereira e Allene Lage (2017) consideram que a introjeção

\footnotetext{
9 As letras são empregadas para aludir aos diversos sujeitos que compõem o movimento - lésbicas, gays, bissexuais, transexuais, travestis, transgêneros, queers, intersexuais, assexuais, etc. - e que vão se ampliando, como resultado de organização e representatividade políticas.
} 
da sombra do opressor ocorre quando, por vezes, nas tramas da heteronormatividade, lésbicas, gays, bissexuais, transexuais e travestis imitam e reproduzem normas hegemônicas de ser e estar no mundo como resposta para se defenderem contra a exclusão e o estigma.

A introjeção dessa sombra do opressor é consequência de uma vigilância constante que oprime os sujeitos sexuais dissidentes, caracterizando o que Berenice Bento denomina como "heteroterrorismo".

\begin{abstract}
As reiterações que produzem os gêneros e a heterossexualidade são marcadas por um terrorismo contínuo. Há um heteroterrorismo a cada enunciado que incentiva ou inibe comportamentos, a cada insulto ou piada homofóbica. Se um menino gosta de brincar de boneca, os heteroterroristas afirmarão: "Pare com isso! Isso não é coisa de menino!". A cada reiteração do/a pai/mãe ou professor/a, a cada "menino não chora!", "comportase como menina!", “isso é coisa de bicha!”, a subjetividade daquele que é o objeto dessas reiterações é minada. (BENTO, 2011, p. 552).
\end{abstract}

Nesse sentido, a educação sexual transgressora é também descolonizadora, ao propiciar que sujeitos sexuais dissidentes expulsem a sombra do opressor e se apropriem de uma linguagem política de resistência, tornando-se capazes não apenas de nomear o sofrimento vivido, mas de expressar inéditos-viáveis ${ }^{10}$. Freire (2008, p. 68) destaca que a relação entre "linguagempensamento-mundo" é dialética e que, portanto, "[...] mudar a linguagem faz parte do processo de mudar o mundo".

Fabio Oliveira e Liliana Rodrigues (2018), ancorados em aportes teóricos de Paulo Freire e bell hooks, reafirmam a importância dessa linguagem de resistência na consolidação de uma educação transgressora e transfeminista para travestis e transexuais. Nessa concepção de educação, apropriar-se de uma linguagem que dá sentido a sua existência configura-se como uma forma de libertação. "Libertar implica, neste contexto, poder nomear um fenômeno social de sofrimento que até então não tinha nome" (OLIVEIRA; RODRIGUES, 2018, p. 93).

A linguagem política de resistência ocupa lugar central na luta pela libertação de sujeitos sexuais dissidentes, possibilitando-lhes nomear os fenômenos de sofrimento que vivenciam cotidianamente, em função da imposição da heteronormatividade, do patriarcalismo, do sexismo e do racismo, bem como identificar os novos desafios demandados na construção de respostas para enfrentamento da lesbofobia, transfobia, homofobia, putafobia, etc.

Além de colaborar na nomeação do sofrimento e no engajamento na transformação da realidade, com vistas a superar a opressão identificada, uma educação crítica e transgressora também potencializa o processo de "assunção do sujeito", que só ocorre quando se é capaz de reconhecer-se como alvo de objetificação impingida pelas estruturas opressoras. "A assunção de nós mesmos não significa a exclusão dos outros. É a 'outredade' do 'não eu' ou do tu, que me faz assumir a radicalidade de meu $e \hat{\text { ' }}$ (FREIRE, 1998, p. 46), sendo esse reconhecimento um passo fundamental no sentido da construção da autonomia.

Sujeitos sexuais dissidentes vêm caminhando em direção a sua autonomia. Há marcos que ilustram essa trajetória, como a Revolta de Stonewall ${ }^{11}$, em 1969, nos Estados Unidos; a ocupação

\footnotetext{
${ }^{10}$ O termo é empregado por Freire (2018) para indicar uma situação inédita, ainda não experienciada, mas viável e que pode ser obtida pela ação dos seres humanos no mundo a ser transformado. Esse termo apresenta relação com o conceito de "futuros possíveis", utilizado por bell hooks (2017).

11 Ocorreu no dia 28 de junho de 1969, considerado o dia do Orgulho LGBTQIA ${ }^{+}$e marco desse movimento social. $\mathrm{Na}$ ocasião, a população de gays, lésbicas, bissexuais e transexuais se rebelou contra a opressão policial no bar Stonewall In, ponto de encontro desse grupo. Os sujeitos, ali presentes, se negaram a apresentar a documentação que era exigida nas constantes batidas policiais realizadas no local. Como consequência, os policiais intensificaram suas ofensivas
} 
da catedral de Saint Niæৃier ${ }^{12}$, em 1975, na França; a organização dos movimentos LGBTQIA ${ }^{+}$e dos movimentos de prostitutas, no Brasil, e sua atuação na despatologização de suas identidades e de sua ocupação, no combate ao HIV/AIDS e ao estigma dele decorrente que relegavam esses sujeitos aos chamados "grupos de risco". Por meio de organização e de problematização da realidade e das sexualidades, lésbicas, gays, travestis, transexuais, bissexuais, pansexuais, prostitutas e demais trabalhadoras/es do sexo vêm tecendo os fios de sua autonomia, ao construírem sua autodeterminação, ao lutarem por seus direitos, ao refutarem imagens depreciativas comumente veiculadas sobre si e suas formas de existência que insistem em retratá-la/os como vítimas destituídas de agência, ao se apropriarem de palavras que, outrora, tinham intenção de causar ofensa, positivando-as - como podemos observar nas ações dos movimentos LGBTQIA ${ }^{+}$que têm positivado os termos "bicha", "sapata", "travesti" ou os movimentos de prostitutas que vêm positivando o termo "puta".

Ao positivarem as palavras, sujeitos sexuais ressignificam a si e suas práticas. Nesse movimento, como ressalta Fiori (2018), a palavra não apenas designa as coisas, mas as transforma, não é apenas pensamento, mas constitui-se como "práxis". O diálogo autêntico é aquele que permite a alteridade, isto é, o reconhecimento de si no outro, explicitando o compromisso de engajamento na construção de um mundo comum. Destarte, dizer a sua palavra e pronunciar coletivamente o mundo é uma grande transgressão, sobretudo, quando protagonizada por sujeitos sexuais dissidentes como lésbicas, gays, travestis, transexuais, bissexuais, pansexuais e prostitutas, que, historicamente, sofrem com processos de silenciamento, marginalização e invisibilidade.

Uma educação sexual transgressora tem possibilitado aos sujeitos sexuais dissidentes a construção de sua autonomia e emancipação, na medida em que favorece a pronúncia coletiva do mundo, a rejeição ao fatalismo e o reconhecimento como agentes que fazem sua própria história. Desse modo, tais sujeitos vão percebendo que as situações-limite vivenciadas não são intransponíveis, mas podem ser superadas por meio de sua colaboração e de seu engajamento na transformação da realidade. Seguem, assim, aprendendo a concretizar uma educação como prática da liberdade e deslegitimando o discurso hegemônico - heteronormativo, sexista, racista e patriarcal - nos ensinando que é preciso resistir para existir.

\section{Considerações}

Contrapondo-se àqueles que dizem que a validade da obra freireana pode ser datada ou restrita à certa localidade, Ramon Flecha-García e Lídia Puigvert (1998) observam que, nas páginas escritas por Freire, se encontram temáticas atuais no campo das Ciências Sociais, como a superação do fatalismo, a compreensão crítica da realidade com vistas a sua transformação, a construção de um diálogo comum entre vozes diferentes, a proposição da igualdade de diferenças, dentre outras. Essas temáticas e os aportes freireanos vão sendo ressignificados e atualizados por educadoras/educadores, integrantes de movimentos sociais, pesquisadoras/pesquisadores, dentre outras e outros que se identificam com a sua concepção de educação como prática da liberdade.

fazendo uso de violência. A população LGBTQIA+ respondeu à altura e também fez uso de violência. O conflito se intensificou e os policiais foram obrigados a se abrigarem dentro do bar, fazendo barricadas para evitar a entrada da multidão que se voltou contra eles (LELIS, 2019).

${ }^{12}$ Considerado o marco dos movimentos de prostitutas, ocorreu no dia 2 de junho de 1975 , culminando no dia internacional da prostituta, denominado no Brasil como o Puta Dei. A manifestação foi realizada por cerca de cem prostitutas que ocuparam a catedral, em Lyon, como forma de reivindicar melhores condições de trabalho e denunciar a repressão policial e o controle estatal (MARTINS, 2020).

Práxis Educativa, Ponta Grossa, v. 16, e2116462, p. 1-18, 2021 
Ratificando esse entendimento, Paula e Mello (2016, p. 65) afirmam que a pedagogia progressista de Paulo Freire "[...] indica caminhos revolucionários para o fortalecimento dos educadores, na condução de suas lutas por melhores condições de trabalho e de carreira, melhores salários, melhor qualidade da educação e das escolas, melhor formação”.

A fim de desvelar as ressonâncias do pensamento e do legado freireano, este ensaio se debruçou a analisar como os aportes de Paulo Freire vêm colaborando com a proposição de uma educação sexual transgressora e emancipadora comprometida com os processos de construção de autonomia e emancipação de sujeitos sexuais dissidentes, tais como lésbicas, gays, travestis, transexuais, bissexuais, pansexuais e prostitutas. Como já nos alertava Paulo Freire, a convivência de diferentes culturas não é natural e não se tece pela espontaneidade, "[...] é uma criação histórica que implica decisão, vontade política, mobilização" (FREIRE, 2008, p. 157) e organização de cada grupo cultural na tecitura de um mundo comum, com finalidades comuns. Isso demanda uma "prática educativa coerente com esses fins" e "uma nova ética fundada no respeito" e na valorização das diferenças (FREIRE, 2008, p. 157). A educação sexual transgressora e emancipadora pode auxiliar-nos a tecer os fios plurais desse mundo comum.

Alicerçada, na concepção de educação como prática da liberdade, e nos escritos de Paulo Freire e bell hooks, a educação transgressora e emancipadora se funda em premissas como: 1) coerência entre teoria e prática, favorecendo um uso contra-hegemônico da teoria que pode figurar como lugar de cura; 2) inserção crítica na realidade e problematização da heteronormatividade, sexismo, machismo, racismo, patriarcalismo e neoliberalismo, permitindo expulsar à sombra do opressor e descolonizar os modos de ser e estar no mundo; 3) apropriação de uma linguagem política de resistência que possibilita não apenas nomear o sofrimento, mas transformar as maneiras de perceber o mundo e construir inéditos viáveis; 4) assumir-se como sujeito e afirmar sua agência nos processos de transformação da realidade; e 5) construir sua autonomia pela sua autodeterminação e organização.

Em consonância aos preceitos freireanos, os modos de existir e resistir protagonizados por sujeitos sexuais dissidentes vêm nos ensinando que a transgressão é uma ação viável no enfrentamento às ofensivas neoliberais do sistema capitalista, evidenciando que suas maneiras plurais de ser e atuar no e com o mundo figuram como contribuições relevantes na caminhada rumo à superação das marcas de colonialidade que ainda assolam nossas vidas.

\section{Referências}

ALTHUSSER, L. Ideologia e aparelhos ideológicos do Estado: notas para uma investigação. Lisboa: Editorial Presença, 1986.

ANDRADE, C. D. Rosa do povo. São Paulo: Círculo do Livro, 1988.

BENEVIDES, B. G.; NOGUEIRA, S. N. B (org.). Dossiê dos assassinatos e da violência contra travestis e transexuais brasileiras de 2019. São Paulo: Expressão Popular, ANTRA, IBTE, 2020.

BENTO, B. Na escola se aprende que a diferença faz a diferença. Revista de Estudos Feministas, Florianópolis, v. 19, n. 2, p. 549-559, ago. 2011. DOI: https://doi.org/10.1590/S0104-026X2011000200016

BETTO, F. Escola sem partido? In: AÇÃO EDUCATIVA. (org.). A ideologia do movimento Escola Sem Partido: 20 autores desmontam o discurso. São Paulo: Ação Educativa, 2016. p. 6567. 
BRASIL. Lei $N^{\circ}$ 9.394, de 20 de dezembro de 1996. Estabelece as diretrizes e bases da educação nacional. Diário Oficial da União: seção 1, Brasília, DF, n. 248, p. 27833-27841, 23 dez. 1996.

BRASIL. Lei No 10.639, de 9 de janeiro de 2003. Altera a Lei nº 9.394, de 20 de dezembro de 1996, que estabelece as diretrizes e bases da educação nacional, para incluir no currículo oficial da Rede de Ensino a obrigatoriedade da temática "História e Cultura Afro-Brasileira", e dá outras providências. Diário Oficial da União: seção 1, Brasília, DF, n. 8, p. 1, 10 jan. 2003.

BRASIL. Lei No 11.645, de 10 março de 2008. Altera a Lei no 9.394, de 20 de dezembro de 1996, modificada pela Lei no 10.639, de 9 de janeiro de 2003, que estabelece as diretrizes e bases da educação nacional, para incluir no currículo oficial da rede de ensino a obrigatoriedade da temática "História e Cultura Afro-Brasileira e Indígena. Diário Oficial da União: seção 1, Brasília, DF, n. 48, p. 1, 11 mar. 2008.

BRASIL. Lei $\mathbf{N}^{\mathbf{0}}$ 12.612, 13 de abril de 2012. Declara o educador Paulo Freire Patrono da Educação Brasileira. Brasília: Presidência da República, Casa Civil, Subchefia para Assuntos Jurídicos, [2012a]. Disponível em: http://www.planalto.gov.br/ccivil_03/_Ato20112014/2012/Lei/L12612.htm. Acesso em: 12 jul. 2020.

BRASIL. Lei $\mathbf{N}^{\mathbf{0}} \mathbf{1 2 . 7 1 1}$ de 29 agosto de 2012. Dispõe sobre o ingresso nas universidades federais e nas instituições federais de ensino técnico de nível médio e dá outras providências. Brasília: Presidência da República, Casa Civil, Subchefia para Assuntos Jurídicos, [2012b]. Disponível em: http://www.planalto.gov.br/ccivil_03/_ato2011-2014/2012/lei/112711.htm. Acesso em: 12 jul. 2020.

BRASIL. Projeto de Lei do Senado $\mathbf{n}^{0} \mathbf{1 9 3} / 2016$. Inclui entre as diretrizes e bases da educação nacional o Programa Escola Sem Partido. Brasília: Câmara dos Deputados, [2016]. Disponível em: http://www.senado.leg.br/atividade/rotinas/materia/getPDF.asp?t=192259\&tp=1. Acesso em: 12 jul. 2020.

BRASIL. Supremo Tribunal Federal. Suspensa lei alagoana que instituiu o programa Escola Livre. Notícias STF, 22 mar. 2017a. Disponível em: https://bit.ly/2XxfYGa. Acesso em: 28 dez. 2020.

BRASIL. Supremo Tribunal Federal. Suspensa norma de município do PR que proíbe ensino sobre gênero e orientação sexual. Notícias STF, 20 jun. 2017b. Disponível em: http://www.stf.jus.br/portal/cms/verNoticiaDetalhe.asp?idConteudo=347188. Acesso em: 28 dez. 2020.

BRASIL. Supremo Tribunal Federal. Lei municipal que proíbe ensino sobre questões de gênero é inconstitucional. Notícias STF, 29 abr. 2020. Disponível em: https://bit.ly/35x2ONx. Acesso em: 28 dez. 2020.

CHADE, J. Cruzada ultraconservadora do Brasil na ONU afeta até resolução contra mutilação genital feminina. El País, Genebra, 8 jul. 2020. Disponível em: https://brasil.elpais.com/brasil/2020-07-09/cruzada-ultraconservadora-do-brasil-na-onu-afetaate-resolucao-contra-mutilacao-genital-feminina.html\#? sma=newsletter _brasil_diaria20200709. Acesso em: 10 jul. 2020.

FIORI, E. M. Aprenda a dizer sua palavra. In: FREIRE, P. Pedagogia do oprimido. 65. ed. Rio de Janeiro: Paz e Terra, 2018. p. 11-30. 
FLECHA-GARCÍA, R.; PUIGVERT, L. Aportaciones de Paulo Freire a la educación y las ciencias sociales. Revista Interuniversitaria de Formación del Profesorado, n. 33, p. 21-28, set./dez. 1998.

FREIRE, P. Educação como prática da liberdade. 36. ed. Rio de Janeiro: Paz e Terra, 2014.

FREIRE, P. Educação e mudança. Rio de Janeiro: Paz e Terra, 2010.

FREIRE, P. Pedagogia da autonomia: saberes necessários à prática educativa. 7. ed. São Paulo: Paz e Terra, 1998.

FREIRE, P. Pedagogia da esperança: um reencontro com a pedagogia do oprimido. 15. ed. Rio de Janeiro: Paz e Terra, 2008.

FREIRE, P. Pedagogia do oprimido. 65. ed. Rio de Janeiro: Paz e Terra, 2018.

FREIRE, P. Política e educação: ensaios. 7. ed. São Paulo: Cortez, 2003.

GIROUX, H. A. Pedagogia crítica, Paulo Freire e a coragem para ser político. Revista eCurriculum, São Paulo, v. 14, n. 1, p. 296-306, jan./mar. 2016.

HOOKS, B. Ensinando a transgredir: a educação como prática da liberdade. 2. ed. São Paulo: Editora Martins Fontes, 2017.

LELIS, R. C. Transviado também faz revolução! Um olhar maquiaveliano sobre a Revolta de Stonewall. Revista de Ciências do Estado, Belo Horizonte, v. 4, n. 2, e15170, p. 1-16, dez. 2019.

LOURO, G. L. Pedagogias da sexualidade. In: LOURO, G. L. (org.). O corpo educado. Belo Horizonte: Autêntica, 2007. p. 8-34.

MARTINS, R. 2 de junho: dia internacional das trabalhadoras sexuais. Mundo Invisível, 1 jun. 2020. Disponível em: https://mundoinvisivel.org/2-de-junho-dia-internacional-dastrabalhadoras-sexuais/. Acesso em: 14 jul. 2020.

MASAGÃO, V. Apresentação. In: AÇÃO EDUCATIVA. (org.). A ideologia do movimento Escola Sem Partido: 20 autores desmontam o discurso. São Paulo: Ação Educativa, 2016. p. 5-8.

OLIVEIRA; F. A. G.; RODRIGUES, L. Por uma educação TRANSgressora e TRANSfeminista: possíveis enfrentamentos à produção das ausências através da disciplinarização e subjetivação. Aprender - Caderno de Filosofia e Psicologia da Educação, Vitória da Conquista, ano XII, n. 20, p. 83-102, dez. 2018. DOI: https://doi.org/10.22481/aprender.v0i20.4553

PARKER, R. Cultura, economia política e construção social da sexualidade. In: LOURO, G. L. (org.). O corpo educado. Belo Horizonte: Autêntica, 2007. p. 126-150.

PAULA, L.; MELLO, R. R. As políticas de formação contínua de professores no estado de São Paulo: debatendo perspectivas de transformação a partir da pedagogia progressista freireana. Práxis Educativa, Ponta Grossa, v. 11, n. 1, p. 63-88, jan./abr. 2016. DOI: https://doi.org/10.5212/PraxEduc.v.11i1.0003

PENNA, F. O ódio aos professores. In: AÇÃO EDUCATIVA. (org.). A ideologia do movimento Escola Sem Partido: 20 autores desmontam o discurso. São Paulo: Ação Educativa, 2016. p. 93-100. 
PEREIRA; C. F.; LAGE, A. C. Educação como prática da liberdade para lésbicas, gays, bissexuais, travestis e transexuais: saberes, vivências e (re)leituras em Paulo Freire. Revista Diversidade e Educação, Rio Grande, v. 5, n. 2, p. 68-76, jul./dez. 2017. DOI: https://doi.org/10.14295/de.v5i2.7712

QUIJANO, A. Colonialidade do poder, eurocentrismo e América Latina. In: LANDER, E. (org.). A colonialidade do saber: eurocentrismo e ciências sociais - Perspectivas Latino-americanas. Buenos Aires: CLACSO, 2005. p. 107-142.

RAMOS, M. S.; SANTORO, A. C. S. Pensamento freireano em tempo de escola sem partido. Inter-Ação, Goiânia, v. 42, n. 1, p. 140-158, jan./abr. 2017. DOI: https://doi.org/10.5216/ia.v42i1.44076

RAMOS, S. (coord.) A cor da violência policial: a bala não erra o alvo. Relatório de pesquisa. Rio de Janeiro: Rede de Observatórios da Segurança/CESeC, dez. 2020.

RUBIN, G. Pensando o sexo: notas para uma teoria radical das políticas da sexualidade. Tradução Felipe Bruno Martins Fernandes; Revisão Miriam Pillar Grossi. Mar. 2012. Disponível em: https://repositorio.ufsc.br/bitstream/handle/123456789/ 1229/ rubin_pensando_o_sexo.pdf. Acesso em: 12 jul. 2020.

SANTOS, B. S. Para além do pensamento abissal: das linhas globais a uma ecologia de saberes. Novos estudos - CEBRAP, São Paulo, n. 79, p. 71-94, nov. 2007. DOI: http://dx.doi.org/10.1590/S0101-33002007000300004

SANTOS, L. A.; MELO, V.; CAVAlCANTE, M. S. A. O. Paulo Freire e a resistência à naturalização da ordem vigente. Práxis Educativa, Ponta Grossa, v. 16, e2016433, p. 1-15, 2021. DOI: https://doi.org/10.5212/PraxEduc.v.16.16433.008

VASCONCELOS, V. O.; BRANDÃO, C. R. 50 anos de Pedagogia do oprimido: reflexões sobre (re)existência no Brasil e na América Latina. Artes de Educar, Rio de Janeiro, v. 4, n. 2, p. 294313, maio/ago. 2018. DOI: https://doi.org/10.12957/riae.2018.38029

Recebido em 28/07/2020

Versão corrigida recebida em 20/12/2020

Aceito em 21/12/2020

Publicado online em 13/01/2021 